\title{
Ontario's response to COVID-19 shows that mental health providers must be integrated into provincial public health insurance systems
}

\author{
Deborah Scharf $^{1}$ (D) $\cdot$ Kirsten Oinonen ${ }^{1}$
}

Received: 4 May 2020 / Accepted: 24 July 2020 / Published online: 7 August 2020

(C) The Canadian Public Health Association 2020

\begin{abstract}
The fear, grief, social isolation, and financial and occupational losses from COVID-19 have created a mental health crisis. Ontario's response highlights the shortcomings of its physician-only public healthcare system that limits public access to appropriate and sustainable mental healthcare. Specifically, Ontario's attempt to rapidly expand mental healthcare access in response to COVID-19 includes new Ontario Health Insurance Program (OHIP) billing codes that enable physicians to provide telephonic trauma counselling and patient self-serve online tools while psychologist and other registered mental health provider services have been largely left out of the provincial response. Why? Non-physician mental health providers operate outside of the provincial healthcare infrastructure, including the provincial payer (i.e., OHIP) that facilitated the provincial physician response. A physician-centric mental healthcare system limits public access to quality, sustainable, evidence-based mental health services because most physicians do not have the capacity, training, or desire to provide mental health services. To improve public access to needed mental health services, provinces should integrate psychologists and other registered mental health providers directly into their public health insurance systems. Integrated providers can be strategically and sustainably mobilized to respond to COVID-19 and future mental health crises.
\end{abstract}

\section{Résumé}

La peur, la tristesse, l'isolement social et les pertes financières et professionnelles dus à la COVID-19 ont fait naître une crise de santé mentale. La riposte de l'Ontario met en évidence les insuffisances de son système de soins de santé strictement axé sur les médecins, qui limite l'accès du public à des soins de santé mentale appropriés et durables. En particulier, la tentative du gouvernement provincial d'élargir rapidement l'accès aux soins de santé mentale en réponse à la COVID-19 inclut de nouveaux codes de facturation au Régime d'assurance-santé de l'Ontario (Assurance-santé) qui permettent aux médecins d'offrir du counseling traumatologique par téléphone et des outils libre-service en ligne à leurs patients, tandis que les services des psychologues et autres dispensateurs autorisés de soins de santé mentale sont pour la plupart exclus de l'intervention provinciale. Pourquoi? Les dispensateurs de soins de santé mentale autres que les médecins évoluent en dehors de l'infrastructure provinciale des soins de santé, y compris du payeur provincial (l'Assurance-santé) ayant facilité l'intervention des médecins ontariens. Un système de soins de santé mentale axé sur les médecins limite l'accès du public à des services de santé mentale durables, de qualité et fondés sur les preuves, car la plupart des médecins n'ont ni la capacité, ni la formation, ni le désir d'offrir des services de santé mentale. Pour améliorer l'accès du public aux services de santé mentale nécessaires, les provinces devraient directement intégrer les psychologues et autres dispensateurs autorisés de soins de santé mentale dans leur système d'assurance-santé. Les dispensateurs intégrés peuvent être stratégiquement et durablement mobilisés pour riposter à la COVID-19 et aux futures crises de santé mentale.

Keywords COVID-19 $\cdot$ Mental health $\cdot$ Public health insurance $\cdot$ Physicians $\cdot$ Equity $\cdot$ Sustainability

Mots-clés COVID-19 $\cdot$ santé mentale $\cdot$ assurance-santé $\cdot$ médecins $\cdot$ équité $\cdot$ durabilité

Deborah Scharf

dscharf1@lakeheadu.ca

1 Department of Psychology, Lakehead University, 955 Oliver Rd, Thunder Bay, ON P7B 5E1, Canada

\section{COVID-19 has created a mental health crisis}

Millions of Canadians are experiencing fear, social isolation, grief, and financial insecurity from COVID-19 that are 
negatively impacting their mental health, whether or not they become infected. Particularly vulnerable groups include frontline workers witnessing death and human suffering while worrying about contracting the virus and bringing it home to their families. People with pre-existing mental health issues who were struggling with the status quo must now also manage pandemic-related stressors, including caring for children at home; these individuals will likely need intensified mental health supports. In addition, family members of long-term care residents may require support to cope with stress or bereavement issues. COVID-19-related mental illness is a looming crisis that needs a coordinated public health response.

\section{Ontario's response to the COVID-19 mental health crisis is physician-centric and therefore problematic}

Ontario's response to the COVID-19 mental health crisis has focused on Ontario Health Insurance Plan (OHIP)-covered primary medical providers to increase the intensity and scope of available mental healthcare. On March 13, 2020, Ontario released new OHIP billing codes that enable physicians to provide crisis counselling to patients over the phone (Ministry of Health 2020a). The Ontario Ministry of Health's COVID-19 resource page (Ministry of Health 2020b) lists this resource first for people experiencing mental health issues during COVID-19, followed by a variety of public services that are well known to be underfunded, with 6-month wait-lists (Health Quality Ontario 2015), and without any publicized new capacity to meet the emergent need.

Several problems exist with directing people experiencing mental health crises to primary care physicians:

1 Ontario physicians typically do not provide psychotherapy (Kurdyak et al. 2020). This is because physicians are typically not trained to provide evidence-based psychotherapies, and psychotherapy if not done properly can be harmful (Rose et al. 2002). Policy actions that direct people with mental health needs to primary care providers therefore pressures and incentivizes over-worked physicians to potentially provide suboptimal care.

2 Payment incentives in medicine have not typically increased public access to evidence-based mental health care (Rudoler et al. 2017), nor have they increased the number of physicians providing the targeted healthcare (Kiran et al. 2012).

3 Shortages of psychiatrist and other public mental health services mean that physicians have nowhere within the public system to refer their patients with severe or emergency mental health issues (Health Quality Ontario 2015).

4 A physician-first approach to emergency mental healthcare pressures an already overburdened primary healthcare system, particularly in rural and northern areas where many people cannot access primary care (Health Quality Ontario 2015).

5 This approach fails to increase public access to psychologists and other non-physician registered mental health providers (RMHPs) who are not covered by OHIP but who may have capacity to provide emergency care that is effective and cost-effective compared with pharmacotherapy alone (Hunsley 2003).

In short, a physician-centric approach to providing emergency mental health services puts patients at risk from inadequate or inappropriate care while increasing stress on primary care providers whose services are desperately needed elsewhere during COVID-19.

\section{No earnest provincial effort has been made to mobilize psychologists and other RMHPs in response to COVID-19}

In March 2020, the Ontario government released its new Roadmap to Wellness, which promises to deliver structured psychotherapy services "funded like OHIP ... with no out-ofpocket cost for clients" (Government of Ontario 2020a). Yet, only links to self-led or online services are currently available (Government of Ontario 2020b). Furthermore, it is not clear whether users can access regulated providers in their area who are aware of local culture and resources, and pathways for people without internet are scant.

Recognizing the mismatch between available services and the public mental health need, non-physician RMHPs have organized their own response to the COVID-19 mental health crisis. The Ontario Psychological Association (OPA), for example, created a Disaster Response Network (DRN) of registered psychologists to donate up to six sessions of psychotherapy to front-line workers free of charge, and as of April 2020, $\mathrm{PhD}$ - and Masters-level providers with expertise in mental health treatment are providing services to the public for free (OPA 2020).

While driven by compassion, this well-intentioned donation of expert services is inequitable and unsustainable, and has several implications for Ontario's mental health system as a whole.

1 It devalues the specialized work of psychologists and RMHPs when policymakers direct the public to provincially-funded physicians rather than funding groups of people who specialize in mental healthcare.

2 Vulnerable people are put at risk when they come to depend on providers whose services are donated and unlikely to stay in place long enough to resolve their complex issues that require care. For example, the DRN's six 
treatment sessions are fewer than the standard of care for trauma-a COVID-19-related issue, which typically requires 12 sessions to resolve (American Psychological Association 2019).

3 Donated care has access issues that do not exist with properly resourced, provincially supported services. For example, psychologists do not typically have access to free provincial telemedicine infrastructure (Ontario Telemedicine Network; OTN), thus limiting the proportion of psychologists who can provide distance care. As a result of this and other capacity issues, the DRN has only publicized itself to select partners, including the Ontario College of Physicians and Nurse Practitioner Association of Ontario. Through these limited networks, the DRN remains accessible to mainly those with primary care.

4 It temporarily but unsustainably blunts the impact of the COVID-19 mental health crisis, therefore decreasing policymakers' impetus to properly resource mental healthcare in the long term. Recently, the City of Toronto asked the DRN to serve survivors of the Yonge Street terror attack, demonstrating that existing mental health services cannot meet the public need. Short-term strategies that mask this long-standing service gap allow people like the Yonge Street terror survivors and people impacted by COVID-19 to fall through the cracks.

\section{An Ontario emergency mental health response requires mental health infrastructure: next steps forward}

COVID-19 shines a light on Ontario's patchwork mental health system that puts vulnerable and sociodemographically disadvantaged people at risk. We are encouraged that the Canadian Institutes of Health Research are allocating funds to support research on mental health service needs during COVID-19 (April 24, 2020). At the same time, other countries already demonstrate how policymakers can mobilize and expand public mental health services by integrating psychologists and other RMHPs into public healthcare systems. Using this knowledge base, Ontario and the rest of Canada could quickly mobilize a network of trained professionals to address the COVID-19 mental health crisis as follows.

1 Create trial billing mechanisms through provincial public health insurance for registered mental health providers with relevant expertise. Payment should be commensurate with professionals' training and expertise and should be developed in consultation with disciplines' professional associations to ensure that providers will be sufficiently incentivized to prioritize and sustain this difficult work. Prospective payment models (PPMs) such as those used to fund the new U.S. Certified Community Behavioral Health Clinics offer replicable templates for estimating and controlling the costs of new and widely expanded mental healthcare (Assistant Secretary for Planning and Evaluation 2019). Hybrid public-private contractual models implemented in Denmark and Norway provide examples of how formerly private providers can be integrated into physician-centric public health systems while controlling costs (Ronis et al. 2017). Models that administratively and financially integrate mental health into general public health insurance can improve care quality and outcomes (Ramanuj et al. 2019).

2 Create standardized provincial required reporting of registered mental health providers and their capacities (e.g., types and amounts of services provided per month, service setting, populations served, distance services capabilities). This will help define the provincial and national mental health service system and its capacity in routine and crisis circumstances, and it will identify critical service gaps and inform meaningful mental health system budgeting and future workforce planning. Reporting of mental health system quality metrics will also ensure value through provider accountability and compensation for work that promotes better public mental health (Ramanuj et al. 2019).

We are aware that many psychologists and other RMHPs might not want their services integrated into the public healthcare system because it could mean less pay and more government oversight and dictation of services. At the same time, mental health professionals must increase their involvement in provincial public health systems as these channels exist to provide sustainable access to healthcare services from providers trained to do the work. Such a change is critical to correcting the current inequities in public access to competent mental healthcare in general, in times of crisis, and into the future.

\section{Conclusion}

The federal government has just announced \$240 million in funding to support online mental healthcare and medical services (May 3, 2020). We hope that federal and provincial governments leverage psychologists and other RMHPs in their response. In Ontario, structural investments that sustainably integrate non-physician RMHPs into the public insurance system are needed to ensure that the province can quickly, effectively, equitably, and sustainably routinely serve its residents, and respond to the current COVID-19 mental health crisis and future crises. 


\section{Compliance with ethical standards}

Conflict of interest Drs. Scharf and Oinonen are registered clinical psychologists with the College of Psychologists of Ontario. They are both employed in university and private practice settings.

\section{References}

American Psychological Association: Guideline Development Panel for the Treatment of PTSD in Adults. (2019). Summary of the clinical practice guideline for the treatment of posttraumatic stress disorder (PTSD) in adults. The American Psychologist, 74(5), 596-607. https://doi.org/10.1037/amp0000473.

Assistant Secretary of Planning and Evaluation. (2019). Certified Community Behavioural Health Clinics Demonstration Program: Report to Congress, 2018. Prospective Payment System Rates (09/ 10/2019).

Government of Ontario. (2020a). Roadmap to wellness: a plan to build Ontario's mental health and addictions system. https://www. ontario.ca/page/roadmap-wellness-plan-build-ontarios-mentalhealth-and-addictions-system. Accessed 9 Jul 2020.

Government of Ontario. (2020b). COVID-19: support for people: learn what financial, mental health and other supports are available during COVID19. https://www.ontario.ca/page/covid-19-support-people\# section-4. Accessed 9 Jul 2020.

Health Quality Ontario. (2015). Taking stock: a report on the quality of mental health and addictions services in Ontario. https://www. hqontario.ca/Portals/0/Documents/pr/theme-report-taking-stock-en. pdf. Accessed 9 Jul 2020.

Hunsley, J. (2003). Cost effectiveness and medical cost-offset considerations in psychological service provision. Canadian Psychology/ Psychologie Canadienne, 44(1), 61-73. https://doi.org/10.1037/ h0085818.

Kiran, T., Victor, J. C., Kopp, A., Shah, B. R., \& Glazier, R. H. (2012). The relationship between financial incentives and quality of diabetes care in Ontario, Canada. Diabetes Care, 35(5), 1038-1046. https:// doi.org/10.2337/dc11-1402.
Kurdyak, P., Zaheer, J., Carvalho, A., de Oliveira, C., Lebenbaum, M., Wilton, A. S., Fefergrad, M., Stergiopoulos, V., \& Mulsant, B. H. (2020). Physician-based availability of psychotherapy in Ontario: a population-based retrospective cohort study. Canadian Medical Association Journal Open, 8, E105-E115. https://doi.org/10.9778/ cmajo.20190094.

Ministry of Health. (2020a). Changes to the Schedule of Benefits for Physician Services (Schedule) in response to COVID-19 influenza pandemic effective March 14, 2020. INFOBulletin, 4745. http:/ www.health.gov.on.ca/en/pro/programs/ohip/bulletins/4000/ bul4745.aspx. Accessed 9 Jul 2020.

Ministry of Health (2020b). Ontario Ministry of Health COVID1-19 fact sheet: resources for Ontarians experiencing mental health and addictions issues during the pandemic. http://www.health.gov.on.ca/en/ pro/programs/publichealth/coronavirus/docs/resources_ontarians_ experiencing_mha.pdf. Accessed 9 Jul 2020.

OPA, 2020. Ontario Psychological Association Disaster Response Network - free psychological services for front-line workers in need (Sylvan Roy, PhD CPsych; Ontario Psychological Association listserv, April 14, 2020).

Ramanuj, P., Ferenchik, E., Docherty, M., Spaeth-Rublee, B., \& Pincus, H. A. (2019). Evolving models of integrated behavioral health and primary care. Current Psychiatry Reports, 21(1), 4. https://doi.org/ 10.1007/s11920-019-0985-4.

Ronis, S. T., Slaunwhite, A. K., \& Malcom, K. E. (2017). Comparing strategies for providing child and youth mental health care services in Canada, the United States, and the Netherlands. Administration and Policy in Mental Health, 44(6), 955-966. https://doi.org/10. 1007/s10488-017-0808-z.

Rose, S. C., Bisson, J., Churchill, R., \& Wessely, S. (2002). Psychological debriefing for preventing post traumatic stress disorder (PTSD). Cochrane Database of Systematic Reviews, 2, CD000560. https://doi.org/10.1002/14651858.CD000560.

Rudoler, D., de Oliveira, C., Cheng, J., \& Kurdyak, P. (2017). Payment incentives for community-based psychiatric care in Ontario, Canada. Canadian Medical Association Journal, 189(49), E1509E1516. https://doi.org/10.1503/cmaj.160816.

Publisher's note Springer Nature remains neutral with regard to jurisdictional claims in published maps and institutional affiliations. 